International Journal of Business and Management 2 (4): 14-20, 2018

e-ISSN: 2590-3721

(C) RMP Publications, 2018

DOI: $10.26666 / \mathrm{rmp} . \mathrm{ijbm} .2018 .2 .3$

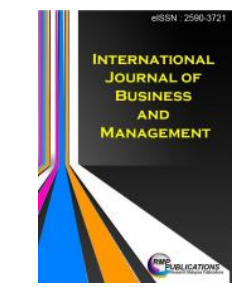

\title{
Innate Factors: The Importance on Earnings Quality in Malaysia
}

Laila binti Musa and Azizee bin Aziz

Politeknik Tuanku Syed Sirajuddin, Pauh Putra, 02600 Arau, Perlis, Malaysia

\begin{abstract}
Innate factors are important determinants of earnings quality of the firm. Most previous studies have not emphasized the potential importance of innate factors individually towards earnings quality. Therefore, this study aims to examine the importance of innate factors as determinant factors of earnings quality in Malaysia. The data collection was made through 2,549 firm year observed data consisting of 728 listed companies in Bursa Malaysia from the year 2006 until year 2010. Data collected were analyzed using panel data regression techniques in determining the influence of economic factors towards earnings quality. Measurement of earnings quality is based on the accrual quality. The results showed that the firm size, variability of cash flows, length of operating cycle, incidence of losses and investment opportunities have a significant influence in describing earnings quality. On the other hand variability of sales and capital intensity proved these factors were not significantly important in describing earnings quality. Overall, this study could give a significant contribution to the literature that innate factors have their own importance as determinant factors of earnings quality in Malaysia.
\end{abstract}

Key words: earnings quality; innate factors

\section{INTRODUCTION}

Earnings is one of the evaluation input to investors in their decision making which will affect the remuneration and the wealth of the firms. This certainly illustrates that earnings quality is very important as a source of investors' dependency in measuring the performance of the firms. Earnings quality is a major source for investors in measuring the firm performance compared to the other sources of performance measurement [1]. Earnings quality also regarded as a key feature in the financial reporting system and considered as a high quality when it improves capital market efficiency [2]. This is because investors view the firm as an entity that generates long-term benefits [3]. Investors and financial information users are more interested in high quality of accounting information.

However, earnings quality is said to have no specific interpretation or in other words it is viewed as a different meaning or different purposes for a different level of users. Generally earnings quality is defined in accounting studies through two different perspectives: decision-making perspective and economic-based perspectives [4]. Under decision-making perspectives, earnings quality is considered high when earnings are particularly very useful for decision-making purposes. While economic-based perspectives viewed earnings quality is considered high when it can show a changes in firm's wealth. According to Francis et al. [5]; Dichev et al. [3], initially earnings quality can be determined by two factors called discretionary factors and innate factors. The sources of discretionary factors arising from the financial reporting process comprise management decisions on financial reporting while innate factors are believed arise from the business model, operational risk and operating environment [5].

Gaio [6] revealed the number of studies that examine the importance of the firms characteristic (also known as innate factors) on the quality of earnings is very limited, whereas previous studies did not deny the ability of innate factors in explaining the importance of earnings quality individually. Most of the previous studies associates their studies in earnings quality with these two determinant factors (i.e. [1], [5], [7] [8], [6], [10]).

Corresponding Author: Laila binti Musa, Politeknik Tuanku Syed Sirajuddin Pauh Putra, 02600 Arau, Perlis, Malaysia, no tel; $+60192586555$ 
In addition, there are also previous studies that consider more on discretionary factors only. In Malaysia, the studies related to discretionary factors (i.e., corporate governance) also be given attention by several authors ([11], [12], [13], [14], [15] and [16]).

Francis et al. [5] found the study results demonstrated the ability of innate factors in explaining the earnings quality are between 50 percent to 70 percent. A review of Dichev et al. [3] also shown the ability of innate factors may explain the earnings quality at the rate of 50 percent. This proves that the innate factors are capable of affecting the earnings quality as well as highlighting the importance of the earnings quality. Following to the arguments by Gaio [6], Francis et al. [5] and Dichev et al. [3] makes that this study is relevant to be investigated. Furthermore, DeFond [17] discuss a review of previous studies by Dechow et al. [18] regarding the lack of attempts by researchers to explain the effects of innate factors can be considered as a challenge in research related to the earnings quality. This means, most of the existing studies tend to focus on issues that can be considered as an accounting and earnings management compared to the basic performance of a firm (i.e., the factors that cannot be observed). In the other words, most existing studies tend to focus on factors that involve discretionary judgment than innate factors.

In general, this study contributes to the existing literature on the earnings quality and particularly on the innate factors as determinants of the earnings quality. It is hoped that this study can bridge the gap between the research on innate factors and discretionary factors that often prevail by the previous studies.

\section{METHODOLOGY}

This study aims to study the importance of innate factors (such as firm size, cash flow variability, variability of sales, operating cycle lengths, losses incidents, capital intensities and investment opportunities) on earnings quality in Malaysia. This study was conducted on 728 firms listed on the main board of Bursa Malaysia, consist of 9 industries. Research samples are widely distributed across multiple industries and reflected most of the industries listed on Bursa Malaysia. Indirectly, firms' sample concentration by industry comprises of industrial products $(40.80 \%)$, consumer products (24.31\%), basic materials (10.85\%) and technology $(10.03 \%)$ that can represented the firm population.
This study involved 2549 firm-years data observation for Dechow and Dichev [19] model and 2717 firm-years data observation for Modified Jones [20] model. Observation of the firm's financial sector is excluded due to its own reporting requirements and have different incentives to manage their earnings and regulated under specific legislation such as the Banking and Financial Institutions Act 1989 [21]. Sample selection and data collection were based on the data available up to 31 December 2011.

This study used one of the accounting-based attributes as a proxy for the measurement of earnings quality - that is accrual quality. Gaio [6] reveals that Francis et al. [1] prove empirically that accrual quality is the most effective attribute of earnings compared to the other attributes such as consistency, predictability, smoothness, value relevance, timing and conservatism. Francis et al. [1] showed that innate factors are more likely to explain the earnings quality through an accrual quality attribute of 55 percent compared to other attributes. This suggests that the availability of innate factors as a determinant of earnings quality is more potent in accounting-based attributes.

The assumption on the innate factors that influence the earnings quality can be described by equations adapted from Francis et al. [1] and Gaio [6].

$$
\begin{aligned}
\mathrm{EQ}_{\mathrm{j}, \mathrm{t}}= & \beta_{0}+\beta_{1} \text { Size }_{\mathrm{j}, \mathrm{t}}+\beta_{2} \sigma(\mathrm{CFO})_{\mathrm{j}, \mathrm{t}}+\beta_{3} \sigma(\text { Sales })_{\mathrm{j}, \mathrm{t}}+ \\
& \beta_{4} \text { OperCycle }_{\mathrm{j}, \mathrm{t}}+\beta_{5} \text { NegEarn }_{\mathrm{j}, \mathrm{t}}+ \\
& \beta_{6} \text { Cap_Intensity }_{\mathrm{j}, \mathrm{t}}+\beta_{7} \operatorname{InvOp}_{\mathrm{j}, \mathrm{t}}+\varepsilon_{\mathrm{t}}
\end{aligned}
$$

where:

\begin{tabular}{|l|l|}
\hline$E_{\mathrm{j}, \mathrm{t}}$ & $\begin{array}{l}\text { Earnings quality for firm } \mathrm{j} \text { in year } \mathrm{t}, \\
\text { using Dechow and Dichev [19] } \\
\text { Model and Modified Jones [20] } \\
\text { Model. }\end{array}$ \\
\hline Size $_{\mathrm{j}, \mathrm{t}}$ & $\begin{array}{l}\text { Firm size }=\text { log of total assets for } \\
\text { firm } \mathrm{j} \text { in year t }\end{array}$ \\
\hline$\sigma(\mathrm{CFO})_{\mathrm{j}, \mathrm{t}}$ & $\begin{array}{l}\text { Cash flow variability = standard } \\
\text { deviation of the firm's rolling 5- } \\
\text { years cash flows from operation for } \\
\text { firm } \mathrm{j} \text { in year t }\end{array}$ \\
\hline$\sigma(\text { Sales })_{\mathrm{j}, \mathrm{t}}$ & $\begin{array}{l}\text { Variability of sales }=\text { standard } \\
\text { deviation of the firm's 5-years sales } \\
\text { revenues for firm } \mathrm{j} \text { in year } \mathrm{t}\end{array}$ \\
\hline OperCycle $_{\mathrm{j}, \mathrm{t}}$ & Length of operating cycle $=$ log of \\
\hline
\end{tabular}




\begin{tabular}{|l|l|}
\hline & $\begin{array}{l}\text { the sum of the firm's days account } \\
\text { receivable and days inventory for } \\
\text { firm } \mathrm{j} \text { in year } \mathrm{t}\end{array}$ \\
\hline NegEarn $_{\mathrm{j}, \mathrm{t}}$ & $\begin{array}{l}\text { Incidence of losses }=\text { proportion of } \\
\text { losses over the years for firm } \mathrm{j} \text { in } \\
\text { year } \mathrm{t}\end{array}$ \\
\hline Cap_Intensity $_{\mathrm{j}, \mathrm{t}}$ & $\begin{array}{l}\text { Capital intensity }=\text { the ratio of the } \\
\text { net book value of PPE to total } \\
\text { assets }\end{array}$ \\
\hline InvOp $_{\mathrm{j}, \mathrm{t}}$ & $\begin{array}{l}\text { Investment opportunity }=\text { the ratio } \\
\text { of net sales for year } \mathrm{t} \text { less net sales } \\
\text { for year } \mathrm{t}-1 \text { to less net sales for year } \\
\mathrm{t}-1 \text { for firm } \mathrm{j} \text { in year } \mathrm{t}\end{array}$ \\
\hline
\end{tabular}

Data were analyzed through panel data regression techniques and three strategies were used: heteroscedasticity test, Pooled Effect Model vs. Fixed Effect Model and Fixed Effect Model vs. Random Effect Model. These three strategies were analyzed according to Dechow and Dichev [19] model and Modified Jones [20] model. Panel data regression analysis was performed for all variables for both model.

\section{FINDINGS AND DISCUSSIONS}

This study viewed the relationship between the innate factors and earnings quality. There were three strategies used before analyzing panel data regression. Table 1(a) (b), Table 2(a) (b) and Table 3 (a) (b) below showed the result of these three strategies.

The first strategy used in hypothesis testing were heteroscedasticity test. Referring to the Table 1(a) and Table 1(b), $\mathrm{p}$ value of the Chi-Square showed a significant value at the significance level of $1 \%$. This means both cross-sectional data in the Dechow and Dichev [19] model and the Modified Jones [20] model showed a heteroscedasticity effect. In this case, the heteroscedasticity issue had been overcome by minimized the value of the variable i.e. $\log$ its value.

Table 1(a): Heteroscedasticity - Dechow dan Dichev [19] Model

Heteroskedasticity Test: Breusch-Pagan-Godfrey

\begin{tabular}{lrlr}
\hline F-statistic & 11.063 & Prob. F(7,2541) & 0.000 \\
$\begin{array}{l}\text { Obs*R-squared } \\
\text { Scaled }\end{array}$ & 75.388 & Prob. Chi-Square(7) & 0.000 \\
explained SS & 49782.30 & Prob. Chi-Square(7) & 0.000 \\
\hline
\end{tabular}

Table 1(b): Heteroscedasticity - Modified Jones [20] Model

Heteroskedasticity Test: Breusch-Pagan-Godfrey

\begin{tabular}{lrll}
\hline F-statistic & 10.904 & Prob. F(7,2709) & 0.000 \\
$\begin{array}{l}\text { Obs*R-squared } \\
\text { Scaled }\end{array}$ & 74.458 & Prob. Chi-Square(7) & 0.000 \\
explained SS & 63975.17 & Prob. Chi-Square(7) & 0.000 \\
\hline
\end{tabular}

Next strategy used in this study was Pooled Effect Model vs. Fixed Effect Model test. The results in Table 2(a) and Table 2 (b) showed that the Pooled Effect model is not suitable for both Dechow and Dichev [19] and Modified Jones [20] models. The p value of the Chisquare Cross-Section/Period $\mathrm{F}$ showed a significant value at the significance level of $1 \%$. As a conclusion for the hypothesis testing through the Redundant Fixed Effects test showed that the Fixed Effect model is suitable for both models.

Table 2(a): Redundant Fixed Effects Test - Dechow dan Dichev [19] Model

Redundant Fixed Effects Tests

Equation: EQ02_FIXED

Test cross-section and period fixed effects

\begin{tabular}{lrrr}
\hline Effects Test & Statistic & d.f. & Prob. \\
\hline Cross-section F & 1.485 & $(677,186)$ & 0.000 \\
Cross-section Chi-square & 1101.640 & 677 & 0.000 \\
Period F & 19.963 & $(4,186)$ & 0.000 \\
Period Chi-square & 107.163 & 4 & 0.000 \\
Cross-Section/Period F & 1.542 & $(681,186)$ & 0.000 \\
Cross-Section/Period & & & \\
Chi-square & 1141.272 & 681 & 0.000 \\
\hline
\end{tabular}

Table 2(b): Redundant Fixed Effects Test Modified Jones [20] Model

Redundant Fixed Effects Tests

Equation: FIXEDvsPOOL

Test cross-section and period fixed effects

\begin{tabular}{lrrr}
\hline Effects Test & Statistic & d.f. & Prob. \\
\hline Cross-section F & 1.528 & $(687,202)$ & 0.000 \\
Cross-section Chi- & & & \\
square & 1137.743 & 687 & 0.000 \\
Period F & 13.104 & $(4,202)$ & 0.000 \\
Period Chi-square & 69.673 & 4 & 0.000
\end{tabular}




\begin{tabular}{lrrr}
$\begin{array}{l}\text { Cross-Section/Period F } \\
\text { Cross-Section/Period } \\
\text { Chi-square }\end{array}$ & $1.537(691,202)$ & 0.000 \\
\hline
\end{tabular}

The last strategy used in the data panel analysis was conducted the Hausman test to identify the suitability of either the Fixed Effect model or the Random Effect model. The findings showed that the $\mathrm{p}$ value of Chisquare Cross-section random was significant at $1 \%$ significance level. Therefore, both Dechow and Dichev [19] and Modified Jones [20] models were not suitable to use the Random Effect model. In other words, the Fixed Effect model was appropriate to be used in this study. As a conclusion for hypothesis testing through the Hausman test showed that the Fixed Effect model was suitable for both Dechow and Dichev [19] model and Modified Jones [20] model. It was clearly demonstrated in Table 3(a) and Table 3(b) below.

Table 3(a): Hausman Test - Dechow dan Dichev [19] Model

Correlated Random Effects - Hausman Test

Equation: EQ02RANDOM

Test cross-section random effects

\begin{tabular}{lrrr}
\hline Test Summary & $\begin{array}{r}\text { Chi-Sq. } \\
\text { Statistic }\end{array}$ & $\begin{array}{r}\text { Chi-Sq. } \\
\text { d.f. }\end{array}$ & Prob. \\
\hline Cross-section random & 144.418 & 7 & 0.000
\end{tabular}

Table 3(b): Hausman Test - Modified Jones [20] Model

Correlated Random Effects - Hausman Test

Equation: EQ02RANDOM

Test cross-section random effects

\begin{tabular}{llrr}
\hline Test Summary & $\begin{array}{r}\text { Chi-Sq. } \\
\text { Statistic }\end{array}$ & $\begin{array}{r}\text { Chi-Sq. } \\
\text { d.f. }\end{array}$ & Prob. \\
\hline Cross-section random & 204.313 & 7 & 0.000 \\
\hline
\end{tabular}

Referring to the panel data regression analysis using Fixed Effect model, Table 4(a) and Table 4(b) clearly shows the influence of innate factors on earnings quality in both Dechow and Dichev [19] model and Modified Jones [20] model.
Table 4(a): Panel Data Regression Analysis Dechow dan Dichev [19] Model

Dependent Variable: EQ_DD

\begin{tabular}{|c|c|c|}
\hline Variable & $\begin{array}{r}\text { Coefficient } \\
\text { estimated sign }\end{array}$ & Coefficient \\
\hline Constant & & $\begin{array}{r}-2.821 * * * * \\
-12.498 \\
(0.000)\end{array}$ \\
\hline Size & - & $\begin{array}{r}0.451 * * * \\
11.765 \\
(0.000)\end{array}$ \\
\hline StdCFO & + & $\begin{array}{r}0.574 * * * \\
3.740 \\
(0.002)\end{array}$ \\
\hline StdSales & + & $\begin{array}{r}0.006 \\
0.139 \\
(0.890)\end{array}$ \\
\hline $\mathrm{OC}$ & + & $\begin{array}{r}0.145 * * * \\
5.061 \\
(0.000)\end{array}$ \\
\hline NegEarn & + & $\begin{array}{r}0.027 * * * \\
4.092 \\
(0.000)\end{array}$ \\
\hline CapInt & + & $\begin{array}{r}0.059 \\
1.268 \\
(0.205)\end{array}$ \\
\hline InvOp & - & $\begin{array}{r}0.015^{* *} \\
2.789 \\
(0.006)\end{array}$ \\
\hline R-squared & & 0.376 \\
\hline $\begin{array}{l}\text { Adjusted R- } \\
\text { squared }\end{array}$ & & 0.147 \\
\hline $\begin{array}{l}\text { S.E. of } \\
\text { regression }\end{array}$ & & 0.161 \\
\hline F-statistic & & 1.643 \\
\hline $\begin{array}{l}\text { Prob (F- } \\
\text { statistic) }\end{array}$ & & 0.000 \\
\hline $\begin{array}{l}\text { Durbin- } \\
\text { Watson stat }\end{array}$ & & 2.065 \\
\hline
\end{tabular}

$(* * *, * *$ and $*$ shows the significance level at $1 \%, 5 \%$ and $10 \%$ respectively) 
Table 4(b): Panel Data Regression Analysis Modified Jones [20] Model

Dependent Variable: EQ_MJones

\begin{tabular}{|c|c|c|}
\hline Variable & $\begin{array}{c}\text { Coefficient } \\
\text { estimated sign }\end{array}$ & Coefficient \\
\hline Constant & & $\begin{array}{r}-2.999 * * * \\
-14.710 \\
(0.000)\end{array}$ \\
\hline Size & - & $\begin{array}{r}0.495 * * * \\
14.318 \\
(0.000)\end{array}$ \\
\hline StdCFO & + & $\begin{array}{r}0.537 * * * \\
3.774 \\
(0.000)\end{array}$ \\
\hline StdSales & + & $\begin{array}{r}0.035 \\
0.888 \\
(0.375)\end{array}$ \\
\hline $\mathrm{OC}$ & + & $\begin{array}{r}0.120 * * * \\
4.568 \\
(0.000)\end{array}$ \\
\hline NegEarn & + & $\begin{array}{r}0.019 * * * \\
3.245 \\
(0.001)\end{array}$ \\
\hline CapInt & + & $\begin{array}{r}0.027 \\
0.642 \\
(0.521)\end{array}$ \\
\hline InvOp & - & $\begin{array}{r}0.017 * * * \\
3.390 \\
(0.001)\end{array}$ \\
\hline R-squared & & 0.353 \\
\hline $\begin{array}{l}\text { Adjusted R- } \\
\text { squared }\end{array}$ & & 0.132 \\
\hline $\begin{array}{l}\text { S.E. of } \\
\text { regression }\end{array}$ & & 0.153 \\
\hline F-statistic & & 1.593 \\
\hline $\begin{array}{l}\text { Prob (F- } \\
\text { statistic) }\end{array}$ & & 0.000 \\
\hline $\begin{array}{l}\text { Durbin- } \\
\text { Watson stat }\end{array}$ & & 1.862 \\
\hline
\end{tabular}

As a result of the panel data regression analysis for both Dechow and Dichev [19] and Modified Jones [20] models through a fixed effect model (after performing three strategies in hypothesis testing), the findings showed that innate factors such as size firms, variability of cash flow, length of operating cycles, incidence of losses, and investment opportunities have significant relationships with the firm's earnings quality in Malaysia. However, the determinant factors of variability of sales and capital intensity factors have not shown the ability to influence earnings quality through non-significant relationships.

Based on Table 4(a) and Table 4(b) above, the findings showed five of the seven innate factors have significant influence on earnings quality based on both Dechow and Dichev [19] and Modified Jones [20] models used in the accrual quality measurement. Findings showed that variability of sales (StdSales) and capital intensity (CapInt) were not influence in describing earnings quality for both Dechow and Dichev [19] and Modified Jones [20] models. This clearly shows that all of the innate factors in this study have an influence in describing earnings quality except for the variability of sales and capital intensity factors. Both models showed that innate factors - firm size (Size), variability of cash flows (StdCFO), length of operating cycle (OC), incidence of losses (NegEarn) and investment opportunities (InvOp) prove to have an influence in describing earnings quality.

In this study Durbin-Watson statistics were not given a focus on the analysis of the findings although the values received were between 0 to 4 . Gujarati [22] revealed that Durbin-Watson's statistics were less taken into account econometrically involving panel analysis due to the sample data was too big. Referring to Table 1, the adjusted R2 values according to the Dechow and Dichev [19] models was 0.147 while the adjusted R2 values according to Modified Jones [20] model shown in Table 2 was 0.132 . This illustrates that innate factors can describe the earnings quality of $15 \%$ through the Dechow and Dichev [19] models as opposed to $13 \%$ through Modified Jones [20] model. However, the percentage difference of innate factors in describing earnings quality in both models of Dechow and Dichev [19] and the Modified Jones [20] was small, only $2 \%$. This suggests that innate factors have an influence in describing earnings quality even though using different 
accrual quality measurement models. Overall, the model of the study was significant to be accepted due to the statistical probability value of $F$ showing a significant value (0.000) at the level of $1 \%$ significance.

\section{CONCLUSION}

This study reveals that innate factors such as firm size, variability of cash flows, length of operating cycle, incidence of losses and investment opportunities have a significant influence in describing earnings quality for both Dechow and Dichev [19] model and the Modified Jones [20] model. Hoever, the innate factors of variability of sales and capital intensity did not explain the influence on the earnings quality in Malaysia. This result were relevant with the some previous studies shown that there were correlation between the innate factors and the earnings quality.

\section{REFERENCES}

[1] Francis J., La Fond R., Olsson P. M. and Schipper K. (2004). Costs of equity and earnings attributes. The Accounting Review. Vol. 79. No. 4. pp. 9671010.

[2] Ewert, R. \& Wagenhofer, A. 2010. Earning Quality Metrics and What They Measure. http://papers. ssrn.com/sol3/papers.cfm?abstract id=1697042.

[19 Jun 2014].

[3] Dichev I. D., Graham J. R., Harvey C. R. and Rajgopal S. (2013). Earnings quality: Evidence from the field. Journal of Accounting and Economics. Vol. 56. pp. 1-33.

[4] Khairul Anuar Kamarudin \& Wan Adibah Wan Ismail. 2014. The Risk of Earnings Quality Impairment. Procedia - Social and Behavioral Sciences. 145:226-236.

[5] Francis J., Olsson P. M. and Schipper K. (2006). Earnings quality. Foundations and Trends in Accounting. Vol. 1. No. 4. pp. 259-340.

[6] Gaio C. (2010). The relative importance of firm and country characteristics for earnings quality around the world. European Accounting Review. Vol. 19. No. 4. pp. 693-738.

[7] Bhattacharya N., Hemang Desai H. and danVenkataraman K. (2008). Earnings quality and information asymmetry: Evidence from trading costs. Accessed on 13 May 2012, available online at: http:// papers. ssrn. com/ sol3/papers. cfm? abstract id $=1266351$.
[8] Laksmana I. and Yang Y. W. (2009). Corporate citizenship and earnings attributes. Advances in Accounting, Incorporating Advances in International Accounting. Vol. 25. pp. 40-48.

[9] Kent P., Routledge J. and Stewart J. (2008). Innate and discretionary accrual quality and corporate governance. Accessed on 20 Jun 2014, available online at: http://epublications.bond.edu.au/ business_pubs $/ 110$.

[10] Garcia-Teruel P. J., Martinez-Solano P. and Sanchez-Ballesta J. P. (2014). Supplier financing and earnings quality. Journal of Business Finance \& Accounting. Vol. 41. No. 9-10. pp. 1193-1211.

[11] Bradbury M., Mak Y. T. and Tan S. M. (2006). Board characteristics, audit committee characteristics and abnormal accruals. Pacific Accounting Review. Vol. 18. No. 2. pp. 47-68.

[12] Romlah Jaffar, Sabariah Jamaludin and Mara Ridhuan Che Abdul Rahman (2007). Determinant factors affecting quality of reporting in annual report of Malaysian companies. Malaysian Accounting Review. Vol. 6. No. 2. pp. 19-42.

[13] Hafiza Aishah Hashim and S. Susela Devi (2008). Corporate governance, ownership structure and earnings quality: Malaysian evidence. Accessed on 12 May 2012, available online at: http:// lby $100 . c o m / l y / 200806 /$ P020080627326811881221.pdf.

[14] Wan Adibah, Dunstan K. and van Zijl T. (2010a). Earnings quality and corporate governance following the implementation of Malaysian code of corporate governance. Accessed on 10 May 2012, available online at: http://works.bepress.com/ keitha_dunstan $/ 5 /$.

[15] Radziah Abdul Latif and Fauziah Taib (2011). The cost of equity effects of accruals quality and ownership structure. Academy of Taiwan Business Management Review. Vol. 7. No. 1.

[16] Hafiza Aishah Hashim and S. Susila Devi (2012). Institutional monitoring and earnings quality in Malaysia. Procedia-Social and Behavioral Sciences. Vol. 65. pp. 419-426.

[17] DeFond M. L. (2010). Earnings quality research: Advances, challenges and future research. Journal of Accounting and Economics. Vol. 50. pp. 402409.

[18] Dechow P., Ge W. and Schrand C. (2010). Understanding earnings quality: A review of the proxies, their determinants and their consequences. 
Journal of Accounting and Economics. Vol. 50. pp. 344-401.

[19] Dechow P. M. and Dichev I. D. (2002). The quality of accruals and earnings: The role of accrual estimation errors. The Accounting Review. Vol. 77. Supplement. pp. 35-59.

[20] Jones J. (1991). Earnings management during import relief investigations. Journal of Accounting Research. Vol. 29. pp. 193-228.

[21] Radziah Mahmud, Muhd. Kamil Ibrahim \& Wee Ching Pok. 2009. Earnings Quality Attributes and Performance of Malaysian Public Listed Firms. http://papers.ssrn.com/ abstract $=1460309[2 \mathrm{Mei}$ 2012]

[22] Gujarati, D. 2013. e-Study Guide for: Basic Econometrics. Edition 5. ISBN 9780073375779 